ISSN 0103-5150

Fisioter. Mov., Curitiba, v. 30, n. 2, p. 267-275, Apr./June 2017

Licenciado sob uma Licença Creative Commons

DOI: http://dx.doi.org/10.1590/1980-5918.030.002.A007

\title{
Evolution of disability in traffic accident victims in rehabilitation, characterized by the International Classification of Functioning, Disability and Health (ICF)
}

\author{
Evolução da deficiência em vítimas de acidente de trânsito em \\ reabilitação, caracterizada pela Classificação Internacional \\ de Funcionalidade, Incapacidade e Saúde (CIF)
}

\author{
Ligia Regina de Oliveira ${ }^{[a]}$, Ana Paula Fontes da Silva Macedo ${ }^{[a]}$, Cássia Maria Buchalla ${ }^{[b]}$, \\ João Henrique Gurtler Scatena ${ }^{[\mathrm{a}]^{*}}$
}

[a] Universidade Federal de Mato Grosso (UFMT), Cuiabá, MT, Brazil

[b] Universidade de São Paulo (USP), São Paulo, SP, Brazil

\section{Abstract}

Introduction: The International Classification of Functioning, Disability and Health (ICF) enables monitoring of the clinical evolution of a patient. Objective: This study aimed to characterize the evolution of disabilities in patients undergoing physical therapy following traffic accidents, using the ICF. Methods: A longitudinal study of 53 accident victims was conducted between April and October 2010, in a rehabilitation unit in the capital of Mato Grosso State, Brazil. Data from physical therapy evaluation were collected in 2 stages and coded by the ICF. Results: The average time between evaluation and reevaluation was 73.4 days. The evolution of functional impairment demonstrated a reduction in the number of patients with deficits, except for muscle tone functions. On initial evaluation, $90.6 \%$ had difficulty with sensory functions and pain, varying from mild to complete, decreasing to $67.9 \%$ on reevaluation, with pain still mostly present. Almost all patients (96.2\%) had a disability of neuromusculoskeletal and movement related functions

"LRO: PhD, email: lrdoliveira@gmail.com APFSM: MS, email: ap.fontess@bol.com.br CMB: PhD, email: cmbuchal@usp.br JHGS: PhD, email: jscatena@terra.com.br 
on initial assessment, with a decrease to $15.7 \%$ of patients on reevaluation. The greatest improvements were observed in the categories of muscle strength (36.7\%) and gait pattern (30.6\%). On reevaluation, improvement was also observed regarding perceived impairment of body structures, especially for those with severe and complete disability. Conclusion: The study confirmed a reduction in the percentage of patients with some form of disability, and positive development in functional capacity. The use of ICF enabled evaluation of physical disabilities and monitoring of the evolution of patients undergoing physical therapy.

Keywords: Disability Evaluation. International Classification of Functioning, Disability and Health. Traffic Accidents. Rehabilitation. Physical Therapy Specialty.

\section{Resumo}

Introdução: A Classificação Internacional de Funcionalidade, Incapacidade e Saúde (CIF) permite acompanhar a evolução clínica do paciente. Objetivo: Este estudo objetivou caracterizar a evolução das deficiências em vítimas de acidentes de trânsito, em tratamento fisioterápico, utilizando essa ferramenta. Métodos: Estudo longitudinal, com total de 53 vítimas de acidentes atendidas entre abril e outubro de 2010 em uma unidade de reabilitação na capital do Estado de Mato Grosso, Brasil. Os dados da avaliação fisioterápica foram coletados em dois momentos e codificados pela CIF. Resultados: $O$ tempo médio entre a avaliação e a reavaliação foi 73,4 dias. Em relação à evolução das deficiências das funções do corpo observou-se redução no número de pacientes com tais alterações, exceto tônus muscular. Na primeira avaliação 90,6\% apresentaram alterações de grau leve a completo quanto às funções sensoriais e dor reduzindo-se para 67,9\% na reavaliação, sendo a dor a função mais comprometida. Em relação às funções neuromusculoesqueléticas e relacionadas ao movimento a quase totalidade dos pacientes (96,2\%) apresentou alguma deficiência na primeira avaliação, percentual reduzido em 15,7\% na reavaliação. As maiores reduções deram-se nas categorias: força muscular (36,7\%) e padrão da marcha (30,6\%). Na reavaliação observouse diminuição das deficiências relacionadas à estrutura do corpo, especialmente nos níveis de deficiência grave e completa. Conclusão: Com este estudo pode-se comprovar a redução no percentual de pacientes com algum tipo de deficiência física e a evolução positiva no quadro funcional. O uso da CIF permitiu conhecer as deficiências físicas e acompanhar a evolução dos pacientes submetidos a tratamento fisioterápico.

Palavras-chave: Avaliação da Deficiência. Classificação Internacional de Funcionalidade. Incapacidade e Saúde. Acidentes de Trânsito. Reabilitação. Fisioterapia.

\section{Introduction}

In the analysis of the health status of a population, mortality and morbidity indicators are primarily used. However, it is necessary to go beyond the limits of such an analysis to measure the loss of health due to disease and injury. A decline in a healthy and full life often leads to use of the healthcare system (1 - 6).

Traffic accidents are a major global public health problem, responsible for 1.2 million deaths and about 20 to 50 million injuries, of which 10 million are disabling and permanent $(2,7)$. In Brazil, the death rate from traffic accidents has been stable, even with an increase in the number and severity of such accidents (8 - 12). Consequently, the number of survivors has increased, and therefore the number of disabled individuals (12). The World Health Organization estimates that by 2020, road accidents will be the third leading cause of disability, and the leading cause in the productive age group $(9-10)$. To put this into perspective, in the last decade, for each person killed in a traffic accident in Brazil, official statistics recorded about 13 injured (13).

Traumatic and non-fatal injuries resulting from accidents and violence result in a gradual reduction of an individual's ability to perform his/her daily activities, with difficulty in performing socially expected functions $(12,14)$. The International Classification of Functioning, Disability and Health (ICF) provides a scientific basis for understanding and studying 
health and health-related conditions, as well as their effects and determinant factors, thereby establishing a common language for describing such conditions; this improves communication between users, and provides a systematic coding scheme to be used by health information systems, enabling increased understanding of health and disease issues (15).

According to the World Report on Disability (16), the principles and applications of the ICF also provide an advance in the understanding and measurement of disability. Moreover, the ICF can be used as a multidisciplinary tool to monitor the stages of evolution of disease or health problems.

The use of ICF in the physical therapy area is recognized by several authors (17 - 21); the ICF is even used to establish recommendations for rehabilitation, and for functional evaluation, planning of therapeutic intervention, and to evaluate the results (22). However, Escorpizo et al. (20) reported that despite the efforts to implement ICF, there is little evidence of use of this tool by physiotherapists. Due to its complexity and scope, there is also little use of the ICF by other health professionals (23). On the other hand, some authors claim that implementation of the ICF by interdisciplinary teams improves the quality of the rehabilitation process $(22,23,24)$.

In a recent systematic analysis on the use of ICF in Brazil (25), the authors found few quantitative observational epidemiological studies, and pointed out the lack of follow-up on the population under analysis. This study aims to characterize the evolution of disabilities in patients undergoing physical therapy due to traffic accidents, using the ICF.

\section{Methods}

An observational longitudinal study was carried out in a reference rehabilitation center for the state of Mato Grosso, aimed at assessing the evolution of physical disabilities in 69 individuals who underwent physiotherapy treatment from April 5 to July 5, 2010, and who had been injured in traffic accidents within 12 months before the start of physical therapy.

Patients were followed up for a maximum of 3 months, and data were collected from April 5 to September 29, 2010 in 2 stages. $1^{\text {st: }}$ Each patient was evaluated (physical and functional assessment) on the first day of treatment; $2^{\text {nd. }}$ a reevaluation was carried out when the patient was discharged, or after 3 months of follow-up; this period was determined by the need to end the study. In addition, the patients who continued treatment in another unit were reevaluated, and home visits were made to collect data. Both the first evaluation and reassessment were carried out by a single researcher with a degree in physical therapy.

Despite undergoing initial evaluation, 15 patients were excluded, because they did not continue treatment at the study venue or in any other rehabilitation setting, and 1 patient could not be located for reassessment. Thus, the study population was composed of 53 individuals.

A specific form was created to record the functional assessment, including anamnesis and physical exam (inspection, pain assessment, palpation, evaluation of movement amplitude, sensitivity tests, tests on manual muscle strength, special orthopedic and/or neurological tests). This instrument was previously tested in 5 patients who were starting orthopedic physical therapy. It was possible to verify the applicability of the form and standardize data collection procedures. Data from the pilot study were not used in the study results.

After collection, data were coded according to 2 ICF components (15): a) Body Function and b) Body Structure. Information about other components (Activity/Participation and Environmental Factors) was also collected, but is not included in this study. As the objective was to assess the evolution of disability, each category was analyzed according to severity level at the time of evaluation and reevaluated. In order to assess the extent (magnitude) of disability for each classification of function and body structure according to the ICF, a qualifier (15) was assigned, as shown in Figure 1.

For the purpose of this study, a disability was considered to be any problem in body function or structure that constitutes a defect, loss, or other important deviation from normal. Body functions are those related to physiological functions of body systems, whereas body structures are anatomical parts of the body, such as organs, limbs and this components (15).

The research was approved by the Research Ethics Committee of the University Hospital Julio Müller at the Federal University of Mato Grosso, Cuiabá, MT, Brazil, under Approval No. 772/CEP-HUJM/10. All participants gave signed informed consent before starting the evaluation. 


\begin{tabular}{|ccl|}
\hline No. & Disability Degree or Level & Meaning \\
\hline 0 & None & The person has no problems. \\
1 & Aild & $\begin{array}{l}\text { A problem that is present less than } 25 \% \text { of the time, with an intensity a person } \\
\text { can tolerate and which happens rarely over the last } 30 \text { days. } \\
\text { A problem that is present less than } 50 \% \text { of the time, with an intensity, which is } \\
\text { interfering in the persons day to day life and which happens occasionally over } \\
\text { the last } 30 \text { days. } \\
\text { A problem that is present more than } 50 \% \text { of the time, with an intensity, which is } \\
\text { partially disrupting the persons day to day life and which happens frequently over } \\
\text { the last } 30 \text { days. } \\
\text { A problem that is present more than } 95 \% \text { of the time, with an intensity, which is } \\
\text { totally disrupting the persons day to day life and which happens every day over } \\
\text { the last } 30 \text { days. }\end{array}$ \\
\end{tabular}

Figure 1 - Qualifying the extent of disability

Note: Adapted from WHO, 2015.

\section{Results}

Of the 53 patients whose evolution could be monitored, $83.0 \%$ (44) were treated at the study venue; most were young (average age $=32$ years), male (62.3\%), and motorcyclists (66.0\%). More than half of the patients had fractures (53.5\%), and most injuries involved lower (43.4\%) and upper (26.4\%) limbs.

The average time between the date of the accident and the first evaluation was 131 days, while the waiting time between this evaluation and the reevaluation was 73.4 days ( $\mathrm{SD}=25.5$ days). The minimum time between the 2 evaluations was 7 days and the maximum was 92 days. The classification at the first visit was based on the ICF, making it possible to concurrently identify deficiencies and disabilities for planning of care.

The body functions classified by ICF in this study were usually sensory functions and pain - $b 2$, and neuromusculoskeletal and movement-related functions b7 (mobility of joint functions, muscle power, muscle tone, and gait pattern). Body structures evaluated were usually related to movement (head and neck region, shoulder, upper extremity, pelvic region, lower extremity and trunk).

With regard to body function, the ICF enabled assessment of the number of patients with specific changes/problems, except for muscle tone. Table 1 shows that the greatest improvements were in the categories of sensation of pain (39.5\%), muscle power (36.7\%), and gait pattern (30.6\%).

With regard to sensory functions and pain (b2), 48 $(90.6 \%)$ subjects were found to have some initial deficits, while at reevaluation the number was reduced to
$36(67.9 \%)$, with pain being the function with greater magnitude on both assessments (Table 1).

Among the 43 who initially reported pain, 39.5\% did not report pain in the reevaluation (Table 2). Severe or complete degree of pain was reported by $65.1 \%$ on initial evaluation, and decreased to $16.3 \%$ on reevaluation, a $75.0 \%$ reduction. There was also a migration from patients initially classified with widespread pain to localized pain on reevaluation.

Regarding neuromusculoskeletal and movementrelated functions (b7), almost all patients (96.2\%) showed some disability on the first evaluation, with a reduction to $15.7 \%$ on reevaluation (Table 1). Among those with disabilities related to mobility of joint functions, 59.6\% had initial severe or complete disability, with a decrease to $23.4 \%$ on reevaluation (Table 3 ).

Concerning muscle power, the results were the same as for the remaining components described above, with severe or complete disability on the first evaluation (48.9\%) evolving to mild or no disability (48.9\%) on reevaluation. It should be noted that the category "no disability", which was not verified during the evaluation, contributed to the highest percentage (36.7\%) on reevaluation (Table 3 ).

Of the 36 patients who presented gait pattern changes at the beginning of treatment, 25 (69.4\%) retained some deficits on reevaluation, with levels of severity (severe or complete) reduced from $52.7 \%$ at initial evaluation to $33.3 \%$ on reassessment (Table 3 ).

All patients presented at least one disability of body structure at the initial evaluation, and 10 (18.9\%) had no disability when they were reevaluated.

Initially, 91 disabilities were identified, with an average of $1.7 /$ patient, while on reevaluation, 
changes in body structure were reduced to 53 , which represents an improvement of $41.8 \%$. Regarding this component, there was a reduction of $63.1 \%$ in the severe and complete disability levels, from the time of initial evaluation to that of reevaluation, and a significant percentage (41.7\%) had no disability at all (Figure 2).
Structures related to movement (s7) were the most compromised, both at the evaluation stage (92.3\%) and on reassessment (88.7\%). However, there was an improvement in the level of this disability. On initial evaluation, a level of complete disability was predominant (44.0\%), but on reevaluation, mild or moderate levels were in the majority $(57.4 \%)$.

Table 1 - Distribution of changes in body function in victims of traffic accidents on initial evaluation and on reevaluation ( $\mathrm{N}=53$ ). Cuiabá/MT, 2010

\begin{tabular}{|c|c|c|c|c|c|}
\hline \multirow{2}{*}{ Changes in body function } & \multicolumn{2}{|c|}{ Evaluation } & \multicolumn{2}{|c|}{ Reevaluation } & \multirow{2}{*}{$\begin{array}{c}\text { Variation } \\
\%\end{array}$} \\
\hline & $\mathrm{n}$ & $\%$ & $\mathrm{n}$ & $\%$ & \\
\hline Sensory functions and pain (b2) & 48 & 90.6 & 36 & 67.9 & -25.0 \\
\hline Touch function (b265) & 14 & 26.4 & 11 & 20.8 & -21.4 \\
\hline Related to temperature and other stimuli (b270) & 15 & 28.3 & 12 & 22.6 & -20.0 \\
\hline Sensation of Pain (b280) & 43 & 81.1 & 26 & 49.1 & -39.5 \\
\hline Sensory functions and pain, other specified (b298) & 5 & 9.4 & 4 & 7.5 & -20.0 \\
\hline $\begin{array}{l}\text { Neuromusculoskeletal and movement- related } \\
\text { functions (b7) }\end{array}$ & 51 & 96.2 & 43 & 81.1 & -15.7 \\
\hline Mobility of joint functions (b710) & 47 & 88.7 & 33 & 62.3 & -29.8 \\
\hline Muscle power (b730) & 49 & 92.5 & 31 & 58.5 & -36.7 \\
\hline Muscle tone (b735) & 5 & 9.4 & 5 & 9.4 & - \\
\hline Gait pattern (b770) & 36 & 67.9 & 25 & 47.2 & 30.6 \\
\hline
\end{tabular}

Table 2 - Distribution of the degree of disability related to sensory function and pain in victims of traffic accidents on evaluation and reevaluation. Cuiabá/MT, 2010

\begin{tabular}{|c|c|c|c|c|}
\hline \multirow{2}{*}{ Disabilities of sensory function and pain } & \multicolumn{2}{|c|}{ Evaluation } & \multicolumn{2}{|c|}{ Reevaluation } \\
\hline & $n$ & $\%$ & $\mathrm{n}$ & $\%$ \\
\hline \multicolumn{5}{|l|}{ Touch function (b265) $n=14$} \\
\hline None & - & - & 3 & 21.4 \\
\hline Mild & 5 & 35.7 & 5 & 35.7 \\
\hline Moderate & 4 & 28.6 & 4 & 28.6 \\
\hline Severe & 1 & 7.1 & 2 & 14.3 \\
\hline Complete & 4 & 28.6 & - & - \\
\hline \multicolumn{5}{|c|}{ Related to temperature and other stimuli (b270) $n=15$} \\
\hline None & - & - & 3 & 20.0 \\
\hline Mild & 5 & 33.3 & 5 & 33.3 \\
\hline Moderate & 4 & 26.7 & 4 & 26.7 \\
\hline Severe & 1 & 6.7 & 3 & 20.0 \\
\hline Complete & 5 & 33.3 & - & - \\
\hline \multicolumn{5}{|l|}{ Sensation of pain (b280) $n=43$} \\
\hline None & - & - & 17 & 39.5 \\
\hline Mild & 6 & 14.0 & 8 & 18.6 \\
\hline Moderate & 9 & 20.9 & 11 & 25.6 \\
\hline Severe & 19 & 44.2 & 6 & 14.0 \\
\hline Complete & 9 & 20.9 & 1 & 2.3 \\
\hline
\end{tabular}


Table 2 - Distribution of the degree of disability related to sensory function and pain in victims of traffic accidents on evaluation and reevaluation. Cuiabá/MT, 2010

\begin{tabular}{lccccc}
\hline \multirow{2}{*}{ Disabilities of sensory function and pain } & \multicolumn{2}{c}{ Evaluation } & & \multicolumn{2}{c}{ Reevaluation } \\
\cline { 2 - 3 } \cline { 5 - 6 } & $\mathbf{n}$ & $\%$ & & $\mathbf{n}$ & $\%$ \\
\hline Sensory functions and pain, other specified (b298) $n=5$ & - & - & & 1 & 20.0 \\
$\quad$ None & 1 & 20.0 & & 2 & 40.0 \\
Mild & 1 & 20.0 & & 1 & 20.0 \\
Moderate & 1 & 20.0 & & 1 & 20.0 \\
Severe & 2 & 40.0 & & - & - \\
Complete & 2 & &
\end{tabular}

Table 3 - Distribution of the degrees of disability related to neuromusculoskeletal and movement-related function in victims of traffic accidents on evaluation and reevaluation. Cuiabá/MT, 2010

\begin{tabular}{|c|c|c|c|c|}
\hline \multirow{2}{*}{ Neuromusculoskeletal and movement-related disabilities } & \multicolumn{2}{|c|}{ Evaluation } & \multicolumn{2}{|c|}{ Reevaluation } \\
\hline & $\mathbf{n}$ & $\%$ & $\mathbf{n}$ & $\%$ \\
\hline \multicolumn{5}{|l|}{ Mobility of joint functions (b710) $n=47$} \\
\hline None & - & - & 14 & 29.8 \\
\hline Mild & 5 & 10.6 & 11 & 23.4 \\
\hline Moderate & 14 & 29.8 & 11 & 23.4 \\
\hline Severe & 13 & 27.7 & 9 & 19.1 \\
\hline Complete & 15 & 31.9 & 2 & 4.3 \\
\hline \multicolumn{5}{|l|}{ Muscle power (b730) $n=49$} \\
\hline None & - & - & 18 & 36.7 \\
\hline Mild & 7 & 14.3 & 6 & 12.2 \\
\hline Moderate & 18 & 36.7 & 17 & 34.7 \\
\hline Severe & 11 & 22.4 & 4 & 8.2 \\
\hline Complete & 13 & 26.5 & 4 & 8.2 \\
\hline \multicolumn{5}{|l|}{ Gait pattern (b770) $n=36$} \\
\hline None & - & - & 11 & 30.6 \\
\hline Mild & 11 & 30.5 & 9 & 25.0 \\
\hline Moderate & 6 & 16.7 & 4 & 11.1 \\
\hline Severe & 11 & 30.6 & 8 & 22.2 \\
\hline Complete & 8 & 22.1 & 4 & 11.1 \\
\hline
\end{tabular}

\section{Discussion}

This study assessed the evolution of disability in patients who had been victims of traffic accidents, at the beginning of treatment and after physical therapy. Changes could be seen in functionality, by using ICF parameters and criteria (15).

Qualifiers that measure the magnitude of disability showed improvement in the health status of patients for both body function and structure. It should be noted that just over half of these patients had not yet completed treatment at the end of the study. A possible third assessment of this group could lead to even more favorable results.

ICF made it possible to follow the evolution of a patient undergoing physical therapy treatment, as several authors have pointed out $(15,26)$, by showing a reduction of disability in relation to body function or structure, as a result of the rehabilitation procedure.

Two ICF categories related to body function were reported as a problem by the vast majority of patients evaluated: i) sensory functions and pain (b2), and neuromusculoskeletal and movement-related function (b7). However, a positive evolution was observed 
in 3 subcategories: pain sensation, muscle strength, and gait pattern.

Among the sensory and pain-related functions (b2), sensation of pain was predominant, both on initial evaluation and at reevaluation. However, there was a sharp reduction in individuals reporting pain on reevaluation, as well as a migration to lower pain levels, or even to absence of pain.

The improvement in symptoms related to changes in body function observed in this study suggests that these disabilities were mostly temporary, and/or that physical therapy was effective.
Concerning neuromusculoskeletal and movementrelated functions (b7), the most relevant categories were those of mobility of joint and muscle power, coinciding with the findings of another study (27). It is believed that the high prevalence of changes in mobility of joint functions and muscle power have been mainly due to the immobilization time required for the consolidation of fractures, the most common injuries in the population studied. A more favorable evolution was observed for disabilities related to muscle power, characterized not only by reduction of such disabilities at reevaluation, but also by reduction of the level of severity.

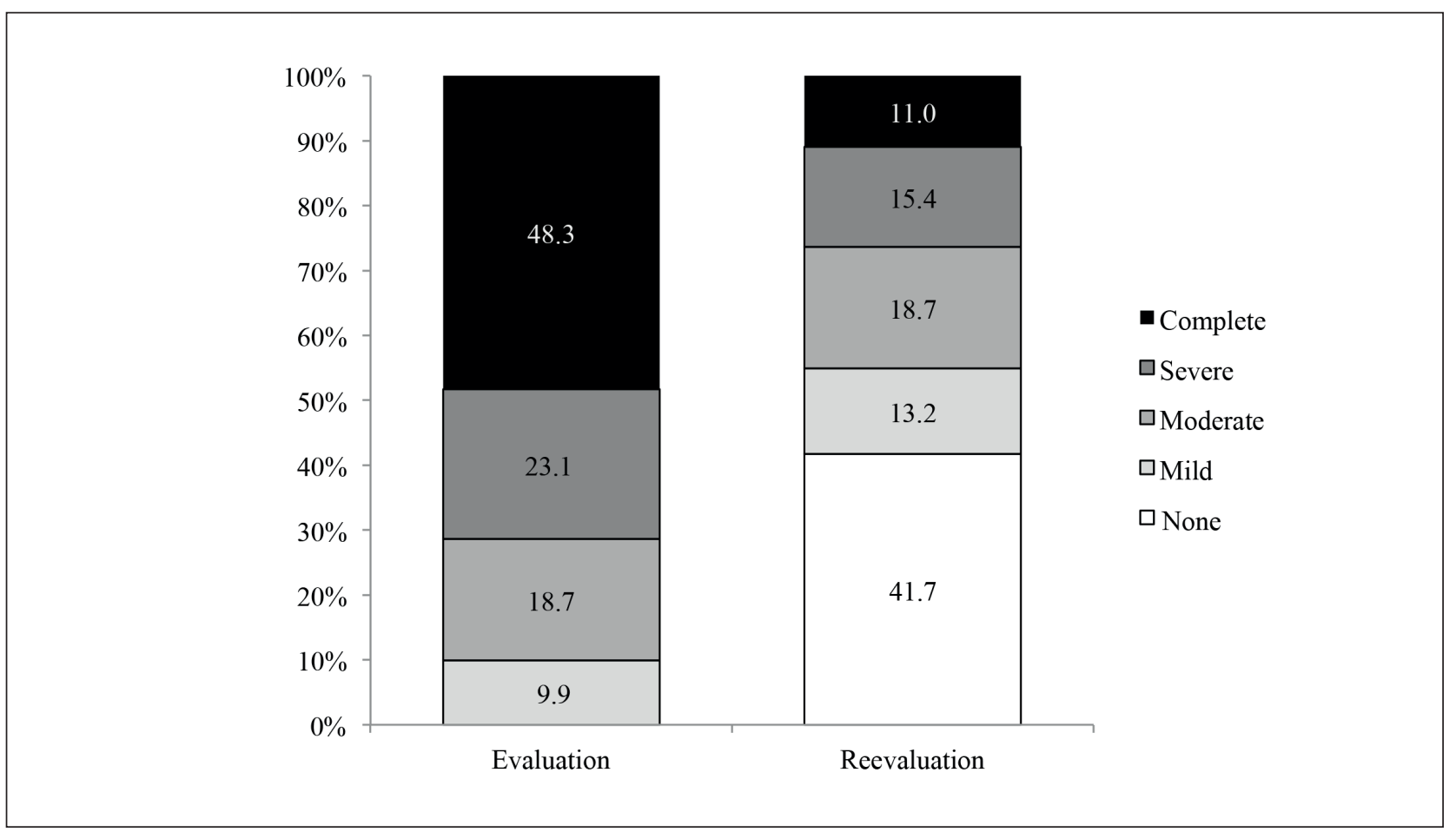

Figure 2 - Distribution of disability levels related to body structure in victims of traffic accidents at the time of evaluation and reevaluation $(\mathrm{N}=91)$. Cuiabá/MT, 2010.

In the studied population, injuries and trauma caused by traffic accidents caused complete or serious disabilities in most compromised structures, as observed during the initial evaluation. As stated by the ICF, a severe or complete disability is one that is present more than $50 \%$ of the time, with an intensity that partially or totally hinders daily life, and is frequently present in the last 30 days (15).

On reevaluation, a decrease in body structure disabilities was recorded, with a significant reduction in the levels of severe and complete disability.
The improvement occurred in all subcategories, especially in movement-related structures.

Motor disabilities, such as those related to cognitive function, are limiting factors preventing a return to autonomy, social participation, and productivity $(12,28,29)$. A literature review (30) related to trauma, rehabilitation, and quality of life concluded that people who have disabilities resulting from trauma generally show limitations in activities and social and occupational participation, with impaired quality of life (30). The improvement in a patient's clinical status, whether 
in relation to body function or structure, contributes to improvement of activities of daily living.

The present study found that disabilities caused by traffic accidents have distinct characteristics and evolution, such that the same injury may affect functional and structural integrity according to the characteristics of the individual. In this regard, Almeida (27) states that the ICF is an advance on attempts to understand the needs and specific conditions of persons with disabilities, and is a tool that enables evaluation of an individual's multi-directional functionality.

Although this study was limited to the analysis of 2 components of the ICF in a very specific population, it proved to be useful in describing the evolution of disabilities in victims of traffic accidents undergoing rehabilitation.

The application of the ICF to health services proved to be feasible and should be encouraged, since it also proved useful as a statistical tool for collecting and recording data. Therefore, considering the scarcity of epidemiological studies using ICF as a research tool, we encourage its use, whether to measure results, quality of life, or other factors.

\section{Conclusion}

This study characterized the evolution of disability in victims of traffic accidents undergoing rehabilitation by emphasizing the importance of the ICF as a tool for classification and description of a disability and its evolution. As shown by the results, application of the ICF revealed an important reduction of severe and complete levels of disability, and demonstrated a positive and reproducible trend when the ICF components were analyzed in greater detail.

Use of the ICF brings a new approach to the assessment of victims of traffic accidents, thus contributing to the understanding of the functionality process inherent to a problem that influences the quality of life.

\section{References}

1. Laurenti R, Buchalla CM. O uso em epidemiologia da família de classificações de doenças e problemas relacionados à saúde. Cad Saude Publica. 1999; 15(4):685-700.
2. Ministério da Saúde. Secretaria de Vigilância em Saúde. Impacto da violência na saúde dos brasileiros. Brasília: Ministério da Saúde; 2005. Portuguese.

3. Costa JLC. Metodologias e indicadores para avaliação da capacidade funcional: análise preliminar do Suplemento Saúde da Pesquisa Nacional por Amostra de Domicílios - PNAD, Brasil, 2003. Cienc Saude Coletiva. 2006;11(4):927-40.

4. Mello Jorge MHP, Koizumi MS. Acidentes de trânsito no Brasil: um atlas de sua distribuição. São Paulo: Associação Brasileira de Medicina de Tráfego; 2007. Portuguese.

5. Ministério da Saúde. Secretaria de Assistência à Saúde. Política Nacional de Saúde da Pessoa Portadora de Deficiência. Brasília: Ministério da Saúde; 2008. Portuguese.

6. Soares BAC, Scatena JHG, Galvão ND. Acidentes e violências na Grande Cuiabá: o que retrata a demanda dos serviços de emergência. Epidemiol Serv Saude. 2009;18(3):265-76.

7. Organização Mundial da Saúde. Relatório mundial sobre violência e saúde. Genebra; 2002.

8. Norin H, Krafft M, Korner J, Nygran A, Tingvall C. Injury severity assessment for car occupants in frontal impacts, using disability scaling. J Clin Epidemiol. 1997;50(1):95103.

9. Mota Jr SC. A mudança da qualidade de vida profissional dos politraumatizados vítimas de acidentes de trânsito [final paper]. Maceió (Brazil): Associação Brasileira de Medicina de Tráfego; 1999. Portuguese.

10. Ameratunga SN, Norton RN, Bennett DA, Jackson RT. Risk of disability due to car crashes: a review of the literature and methodological issues. Injury. 2004;35(11):1116-27.

11. Ameratunga SN, Norton RN, Connor JL, Robinson E, Civil I, Coverdale J, et al. A population-based cohort study of long-term changes in health of car drivers involved in serious crashes. Ann Emerg Med. 2006;48(6):729-36.

12. Mello Jorge MHP, Koizumi MS. Sequelas visíveis de acidentes de trânsito: primeiros dados brasileiros. Abramet. 2012;29(1):36-45. 
13. Mello Jorge MHP, Koizumi MS. Acidentes de trânsito no Brasil: um atlas de sua distribuição. São Paulo: Associação Brasileira de Medicina de Tráfego; 2013. Portuguese.

14. Sampaio RF, Luz MT. Funcionalidade e incapacidade humana: explorando o escopo da classificação internacional da Organização Mundial de Saúde. Cad Saude Publica. 2009;25(3):475-83.

15. Organização Mundial da Saúde. Organização Pan Americana da Saúde. Centro Colaborador da Organização Mundial da Saúde para a Família de Classificações Internacionais. CIF: Classificação Internacional de Funcionalidade, Incapacidade e Saúde. São Paulo: Edusp; 2015. 336p. Portuguese.

16. Organização Mundial da Saúde. Relatório Mundial sobre a Deficiência. São Paulo: SEDPcD; 2012. Portuguese.

17. World Confederation for Physical Therapy (WCPT). 15th WCPT General Meeting; June 4 2003. Barcelona, Spain.

18. Finger ME, Cieza A, Stoll J, Stucki G, Huber EO. Identification of intervention categories for physical therapy, based on the classification of functioning, disability and health: a Delphi exercise. Phys Ther. 2006;86(9):1203-20.

19. Penney J, MacKay-Lyons MJ, McDonald A. EvidenceBased Stroke Rehabilitation: Case Analysis Using the International Classification of Functioning, Disability and Health Framework. Physiother Can. 2007;59(1):22-38.

20. Escorpizo R, Stucki G, Cieza A, Davis K, Stumbo T, Riddle DL. Creating an Interface Between the International Classification of Functioning, Disability and Health and Physical Therapist Practice. Phys Ther. 2010;90(7):1053-63.

21. American Physical Therapy Association (APTA). APTA Endorses World Health Organization ISF Model [cited 2014 Jun 30]. Available from: http://tinyurl.com/ jpz65hp.
22. Rentsh HP, Bucher P, Dommen Nyffeler I, Wolf C, Hefti H, Fluri E, et al. The Implementation of the "International Classification of Functioning, Disability and Health (ICF)" in Daily Practice of Neurorehabilitation: an Interdisciplinary Project at the Kantonsspital os Lucerne, Switzerland. Disabil Rehabil. 2003;25(8):411-21.

23. Riberto M. Core sets da Classificação Internacional de Funcionalidade, Incapacidade e Saúde. Rev Bras Enferm. 2011;64(5):938-46.

24. Scheuringer M, Stucki G, Huber EO, Brach M, Schwarzkopf SR, Kostanjsek N, et al. ICF Core Set for patients with musculoskeletal conditions in early post-acute rehabilitation facilities. Disabil Rehabil. 2005;27(7-8):405-10.

25. Castaneda L, Bergmann A, Bahia L. A Classificação Internacional de Funcionalidade, Incapacidade e Saúde: uma revisão sistemática de estudos observacionais. Rev Bras Epidemiol. 2014;17(2):437-51.

26. Araújo ES. A Classificação Internacional de Funcionalidade, Incapacidade e Saúde (CIF) em fisioterapia: uma revisão bibliográfica [master's thesis]. São Paulo: Faculdade de Saúde Pública da Universidade de São Paulo; 2008. Portuguese.

27. Almeida MCRR. Classificação de Funcionalidade, Incapacidade e Saúde - CIF: aplicação em um hospital público [dissertation]. São Paulo: Faculdade de Saúde Pública da Universidade de São Paulo; 2002. Portuguese.

28. Fechio MB, Pacheco KMB, Kaihami HN, Alves VLR. A repercussão da lesão medular na identificação do sujeito. Acta Fisiátrica. 2009;16(1):38-42.

29. Jácomo AAE, Garcia ACF. Análise dos acidentes automobilísticos no Centro de Reabilitação Dr. Henrique Santillo (CRER). Acta Fisiátrica. 2011;18(3):124-9.

30. De Carlo MMRP, Elui VMC, Santana CS, Scarpelini S, Alves ALA, Salim FM. Trauma, reabilitação e qualidade de vida. Medicina (Ribeirão Preto). 2007; 40(3):335-44.

Received in $10 / 25 / 2015$

Recebido em 25/10/2015

Approved in 07/07/2016

Aprovado em 07/07/2016 